\title{
Isolation of lectin from lamprey serum
}

\author{
Yinglun Han ${ }^{1,2 *}$, Xin Liu ${ }^{1,2 *}$, Xiaoping Song ${ }^{1,3 *}$, Meng Gou ${ }^{1,2 *}$, Yue Pang ${ }^{1,2 *}$ and Qingwei Li ${ }^{1,2 *}$ \\ ${ }^{1}$ College of Life Science, Liaoning Normal University, China \\ ${ }^{2}$ Lamprey Research Center, Liaoning Normal University, China \\ ${ }^{3}$ Affiliated zhongshan Hospital of Dalian University, China \\ \#Equal Contribution
}

\begin{abstract}
A $105-\mathrm{kDa}$ polymer lectin was purified from lamprey (Lampetra japonica) serum. The purification protocol involved ion exchange chromatography with SPSepharose and size exclusion chromatography on Superdex 200. The lectin was adsorbed on SP-Sepharose columns. Finally, the lectin gave an absorbance peak which corresponded to $105 \mathrm{kDa}$ based on results of size exclusion chromatography. Native-PAGE and SDS-PAGE respectively displayed a single band at around 105 $\mathrm{kDa}$ and $35 \mathrm{kDa}$, indicating that the protein exists as a trimer. This protein, after Native-PAGE and SDS-PAGE, was excised from the gel and further analysis by MALDI-TOF/TOF as serum lectin (gi: 13094239). The lectin was able to agglutinate rabbit red blood cells (RRBCs) and sheep red blood cells (SRBCs) in vitro. In this study, we isolated lectin from lamprey serum which might be helpful to deeply research the Variable Lymphocyte Receptors mediate innate immune molecules dependent immune defence in jawless vertebrates.
\end{abstract}

\section{Introduction}

Lectins are carbohydrate-binding proteins that have been investigated extensively in recent years for application in medical and immunology research [1]. They play many different biological functions in animals, from the glycoprotein synthesis to regulation of cell adhesion and the control of protein levels in the blood [2]. At the same, lectins serve many important roles in the innate immune defense by recognizing carbohydrates [3]. They also can agglutinate red blood cells in vitro [4]. Lamprey and hagfish are belong to gnathostomata which comprises of extinct and modern jawless vertebrates. As a group of primitive vertebrates, they not only share several primitive features as the innate immune response system of vertebrates, but also exhibit adaptive immune reaction that possesses antigen-specific immunological memory [5]. Though T cell receptor (TCR) and B cell receptor (BCR) do not exist in lamprey, recent findings have revealed that they possess an alternative immune system that can specifically recognize and respond to external pathogens [6]. This alternative immune system can use genomic leucine-rich-repeat (LRR) cassettes for the combinatorial assembly of diverse antigen receptor genes encoding a vast number of variable lymphocyte receptors (VLRs) for resisting the invasion of pathogens [7]. After being infected by specific a pathogen, VLRB-like lymphocytes expressing specific VLRB molecules undergo amplified expression, and begin to secrete VLRB in a manner analogous to the secretion of immunoglobulins by B cells [7]. The aim of this study was to purify a lectin from lamprey (Lampetra japonica) serum, and to lay a foundation for further research lamprey immune defense mechanisms.

\section{Materials and methods}

\section{Animals and reagents}

The handling of lamprey (Lampetra japonica) and all experimental procedures were approved by the Animal Welfare and Research Ethics Committee of the Institute of Dalian Medical University
(Permit Number: SYXK2004-0029). Adult lampreys were purchased from Tongjiang section of the Heilongjiang River (Tongjiang City, Heilongjiang Province, China) in December. Rabbit red blood cells (RRBCs) and sheep red blood cells (SRBCs) were obtained from rabbit and sheep, respectively. $\mathrm{NaHCO}_{3} \mathrm{C}_{2} \mathrm{H}_{3} \mathrm{~N}$, IAA, TFA were purchased from the Sigma company (Sigma-Aldrich, St. Louis, $\mathrm{MO}$ ). $\mathrm{NaCl}$, coomassie brilliant blue $\mathrm{G} 250, \mathrm{CH}_{3} \mathrm{COOH}$ and the phosphate buffer were of analytical grade from Sangon Biotech (SANGON BIOTECH (SHANGHAI) CO., LTD.). AKTA avant 25 was purchased from the GE Company (GE Healthcare). MALDI-TOF mass spectrometry was purchased from the BRUKER Company (Bruker Daltonics, Bremen, Germany).

\section{Lampreys serum}

Lamprey blood was collected from 100 healthy adult tail-severed lampreys with unknown sex. Normal adult lampreys (200-220g in weight) blood was drawn from tail-severed into a $10 \mathrm{ml}$ plastic centrifuge tube and was allowed to clot at $4^{\circ} \mathrm{C}$ for overnight. Serum was separated by centrifugation ( $4000 \mathrm{rpm}$ ) for $10 \mathrm{mins}$ at $4^{\circ} \mathrm{C}$ and was stored in $1.5 \mathrm{ml}$ centrifuge tube at $-20^{\circ} \mathrm{C}$ before use.

\section{SP-Sepharose chromatography}

Twenty milliliters of lamprey serum were dialyzed against three changes of $6 \mathrm{~L}$ of the starting buffer consisting of $10 \mathrm{mM} \mathrm{NaPB}$ and $5 \mathrm{mM}$ EDTA ( $\mathrm{pH}$ 6.5) for $24 \mathrm{hr}$. The pellets were removed by centrifugation (12000rpm) for $10 \mathrm{~min}$ at $4^{\circ} \mathrm{C}$ and the cleared supernatant was applied

Correspondence to: Yue Pang and Qingwei Li, Liaoning Normal University, Dalian 116029, China, Tel/Fax: +86-411-85827799, E-mail: liqw@263.net

Key words: Lampetra japonica, lectin, purification

Received: October 28, 2017; Accepted: November 23, 2017; Published: November 28, 2017 
to a SP-Sepharose column $(4.5 \times 30.0 \mathrm{~cm})(\mathrm{GE}$ Healthcare) equilibrated with the starting buffer. The column was washed with $1 \mathrm{~L}$ of the starting buffer, and a linear salt gradient was started. The total volume of the gradient was $350 \mathrm{ml}$, and the limiting $\mathrm{NaCl}$ concentration was $600 \mathrm{mM}$. Five milliliter fractions were collected at the flow rate of $50 \mathrm{ml} / \mathrm{hr}$. The eluted protein fraction with hemagglutinating activity was then dissolved in $150 \mathrm{mM} \mathrm{NaCl}$ after the major effluent peak.

\section{Size exclusion chromatography}

The protein of hemagglutinating activity dialyzed against three changes of $6 \mathrm{~L}$ of $10 \mathrm{mM} \mathrm{NaPB}, 5 \mathrm{mM}$ EDTA and $150 \mathrm{mM} \mathrm{NaCl}$ Buffer ( $\mathrm{pH}$ 6.5) for $24 \mathrm{hr}$. The dialyzed sample $(5 \mathrm{ml})$ was applied to size exclusion chromatography on a Sephadex 200 column $(2.0 \times 70.0 \mathrm{~cm})$ (GE Healthcare) equilibrated with the same buffer used for the dialysis of the sample. Elution was carried out at a flow rate of $20 \mathrm{ml} / \mathrm{hr}$, and $1 \mathrm{ml}$ fractions were collected. The lectin gave an absorbance peak which corresponded to $105 \mathrm{kDa}$. Finally, the protein fractions were collected, dialyzed, lyophilized and stored at $-20^{\circ} \mathrm{C}$ for future assay.

\section{Protein concentration measurements}

The protein concentrations of the samples were determined by Bradford assay using bovine serum albumin as standard.

\section{Mass spectrometry}

Purified lectin was electrophoresed by native polyacrylamide gel electrophoresis (Native-PAGE) and SDS polyacrylamide gelelectrophoresis (SDS-PAGE). Albumin from bovine serum 66 $\mathrm{kDa}$ (monomer) and $132 \mathrm{kDa}$ (dimer) were used as Native-PAGE gel molecular-weight standards (Sigma-Aldrich, St. Louis, MO). SDSPAGE was carried out using $12 \%(\mathrm{w} / \mathrm{v})$ gel. Phosphorylase b $(97.2$ $\mathrm{kDa})$, albumin $(66.4 \mathrm{kDa})$, ovalbumin $(44.3 \mathrm{kDa})$, carbonic anhydrase $(29.0 \mathrm{kDa})$ and trypsin inhibitor $(20.1 \mathrm{kDa})$ were used as molecularweight standards for SDS-PAGE (TaKaRa Biotechnology, Dalian, China). These protein bands were visualized with Coomassie Brilliant Blue R-250. Specific protein bands were excised from the gel matrix and subjected to in-gel tryptic digestion. The MALDI-TOF mass spectrometry was operated in the positive ion mode with the following acquisition cycle: a full scan ( $\mathrm{m} / \mathrm{z} 500)$ recorded in the orbitrap analyzer at resolution R 60,000 was followed by MS/MS of the 20 most intense peptide ions in the LTQ analyzer. All MS raw data were searched against all lamprey sequences available in the NCBI database using the MS-Mascot searching algorithm. Search criteria used were as follows: oxidation of Met, carbamidomethylation of Cys, Trypsin, 0.5Da Peptide mass to tolerance, 1 Max missed cleavage Sequence coverage $>10 \%$.

\section{Hemagglutination assay}

In the assay of hemagglutinating activity, a serial twofold dilution of the sample solution in 96 well flat-bottom plates (100 ul) was respectively mixed with $100 \mathrm{ul}$ of a $2 \%$ suspension of RRBCs and SRBCs in phosphate-buffered saline $(\mathrm{pH} 7.2)$ at room temperature for $1 \mathrm{~h}$. After incubation, red blood cells agglutination was observed by light microscopy in vitro. All statistical analyses were performed with the SAS proprietary software release 8.02 and student's two-sample t-test.

\section{Results and discussion}

The lamprey lectin was isolated from serum using SP-Sepharose gel filtration column chromatography. Twenty milliliters $\mathrm{ml}$ of the lamprey serum was added to the column and eluted with $600 \mathrm{mM} \mathrm{NaCl}$ in 50 $\mathrm{mM}$ phosphate buffer, $\mathrm{pH}$ 6.5. Five milliliter fractions were collected and assayed for protein at $280 \mathrm{~nm}$ (Figure 1a). An absorbancy peak of 495 was identified for fraction number 25 . Hemagglutinating activity was found only in $\# 25$. The dialyzed sample (\#25) was applied to size exclusion chromatography on a Sephadex 200 column. It was resolved into a major peak and two minute peaks (Figure 1b). Hemagglutinating activity resided was found only in \#26 which contained the purified lectin. The elution volume of \#26 was approximately $26 \mathrm{ml}$ in size exclusion chromatography on a Superdex 200 column. The elution volume at $26 \mathrm{ml}$ corresponded to a molecular mass of approximately $105 \mathrm{kDa}$. The molecular weight of native Lectin was estimated to be $105 \mathrm{kDa}$, suggesting that this protein exists as a trimer (Figure 1b). Native PAGE analysis was also carried out. The result also supported the idea that lectin exists as a trimer because the molecular weight of native lectin was calculated as $105 \mathrm{kDa}$ (Figure 1c). A single protein band corresponding to lamprey serum lectin was also found in the SDS-PAGE gel (Figure 1c). Its molecular mass was slightly larger than $29.0 \mathrm{kDa}$. Based on its migration distance, it can be deduced that its molecular mass is around $35 \mathrm{kDa}$ from the molecular mass calibration graph. On MS/MS analysis, the protein was identified with significant protein scores $(p>0.05)$ from Mascot searches of peptide mass fingerprints (Figure 1d). The peptide with $\mathrm{m} / \mathrm{z} 1671$ corresponds to the tryptic fragment of the complete sequence (R.WSSQLGSNP.A) (Figure 1d), which identified the protein is serum lectin (gi: 13094239). To examine hemagglutinating activities, we observed the ability of the

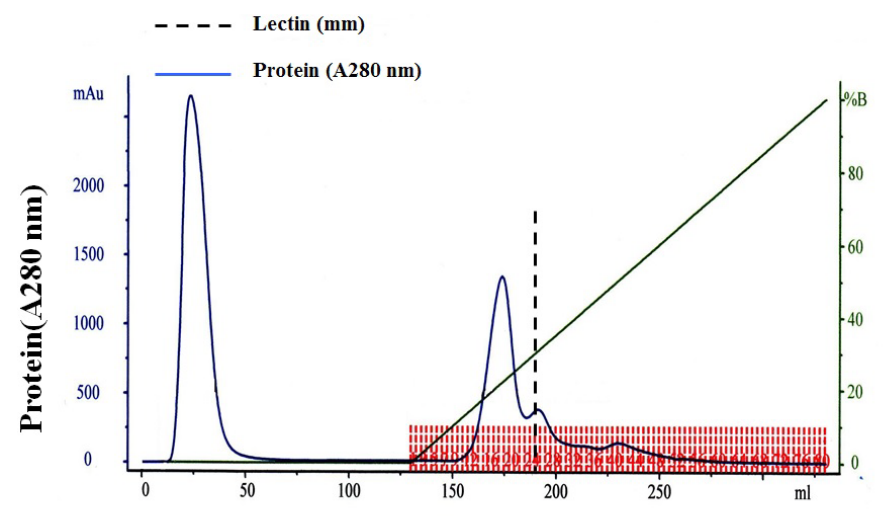

Figure 1a. Ion exchange chromatography profile of lamprey serum crude extract on SP Sepharose. Flow rate $=50 \mathrm{ml} / \mathrm{hr}$. Hemagglutinating activity resided in fraction number 25 . The dotted line indicates lectin.

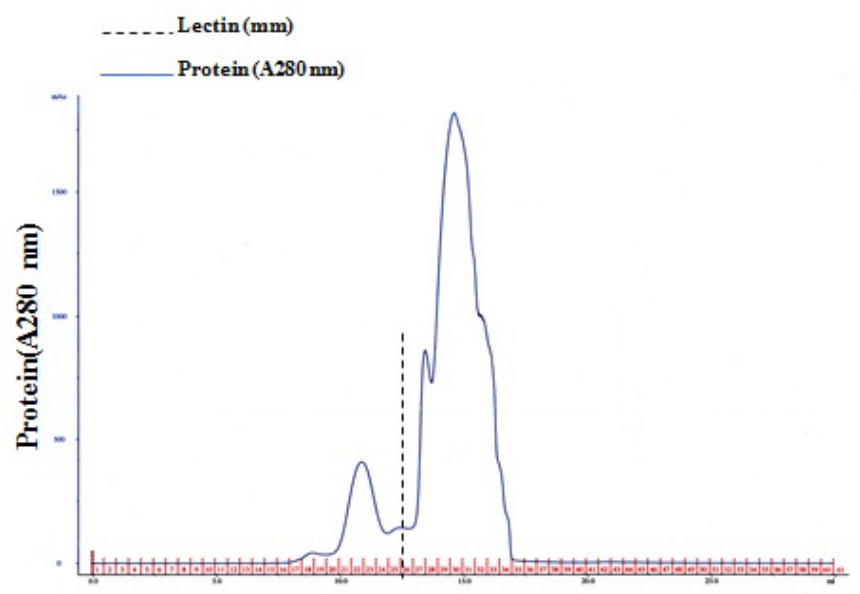

Figure 1b. A Gel filtration profile of fraction number 25 on Superdex 200. Flow rate $=20$ $\mathrm{ml} / \mathrm{hr}$. Hemagglutinating activity resided in fraction number 26 . The dotted line indicates lectin. 
lamprey serum lectin to agglutinate RRBCs and SRBCs. In the group of RRBCs and SRBCs, the agglutinphore group respectively could be observed in the dilution of $12.5 \mathrm{ug}$ and $6.25 \mathrm{ug}$ (Figure 1e). The ability of the lamprey serum lectin to agglutinate SRBCs was slightly stronger than RRBCs. This result suggests that the hemagglutinating activities

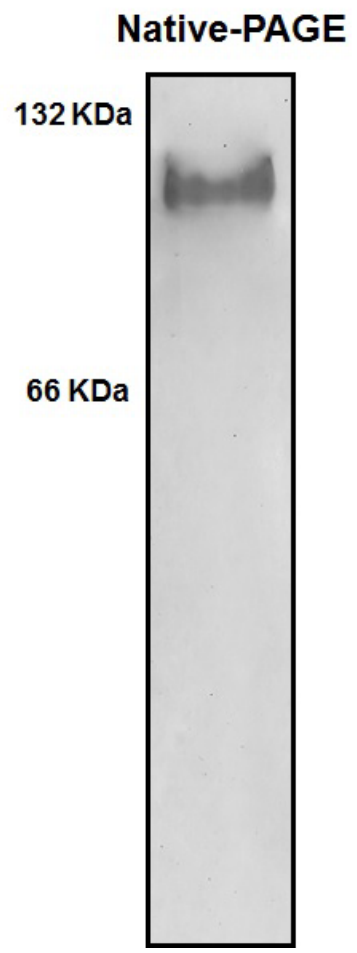

SDS-PAGE

Figure 1c. Gel analyses and Peptide mass fingerprints. (a) native-PAGE and SDSPAGE. Left lane. Native-PAGE. Right lane. SDS-PAGE. (b) The peptide with m/z 1671 corresponds to the tryptic fragment of the complete sequence (R.WSSQLGSNP.A), which identified the protein is serum lectin (gi. 13094239).

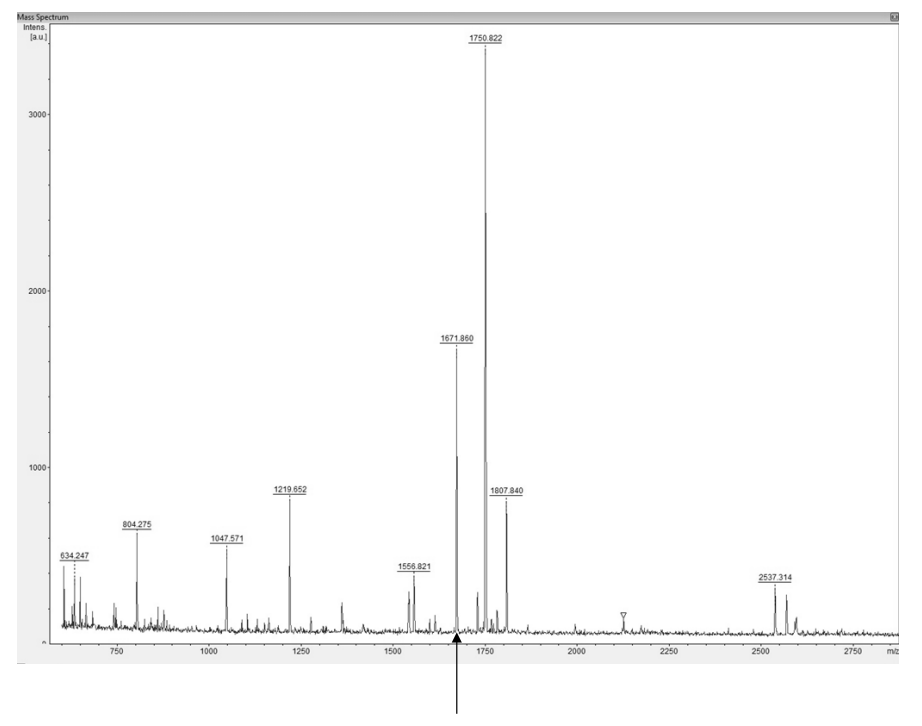

R.WSSQLGSNP.A

Figure 1d. Agglutination assay of lamprey lectin against erythrocytes. The antigens for agglutination assay were RRBCs and SRBCs. Data represent mean numbers \pm SE, Error bars indicated (s.e.m), $\mathrm{n}=3$.

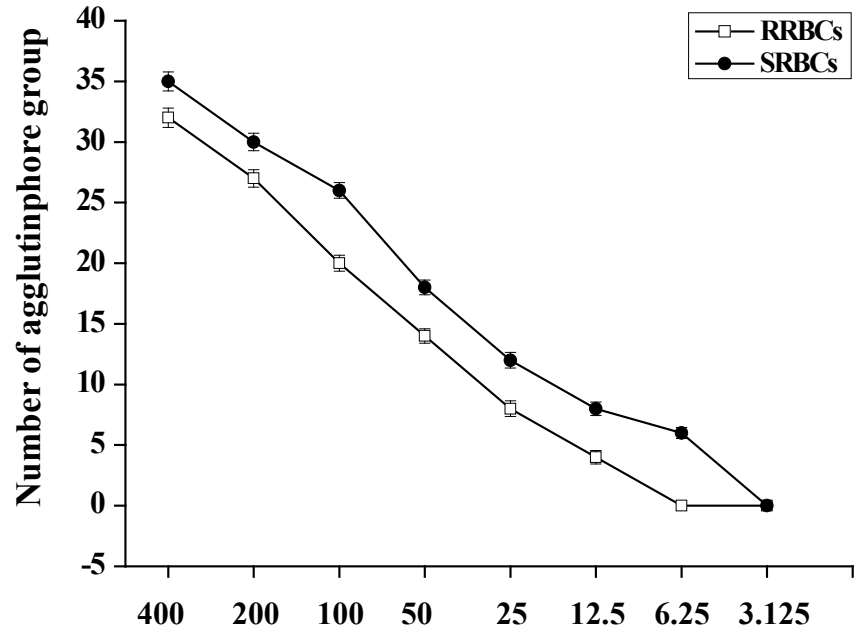

\section{Lectin concentration (ug)}

Figure 1e.

of RRBCs and SRBCs were depended on the dose of lectin. Meanwhile, lamprey serum lection had a protein concentration of $1.45 \mathrm{mg}$ protein/ $\mathrm{ml}$ of serum by BCA assay.

In the current study, we purified a lectin from lamprey L. japonica, a representative of jawless vertebrate. In size exclusion chromatography, the lectin was eluted as a gently peak with a molecular weight of around $105 \mathrm{kDa}$ while SDS-PAGE in reducing conditions revealed a $35-\mathrm{kDa}$ protein band. Meanwhile, Native-PAGE analysis indicated that the molecular weight of native lectin was calculated as $105 \mathrm{kDa}$. Besides, MALDI-TOF/TOF analysis identified the protein is serum lectin (gi: 13094239). These data suggested that the lectin was a 105$\mathrm{kDa}$ trimerical protein, and possesses hemagglutinating activity. Agnathans, represented by lamprey and hagfish, are agreed to be the oldest vertebrates currently possessing the adaptive and innate immune defenses. Variable lymphatic receptors are the important components for adaptive immune response in jawless vertebrates [7]. In jawed vertebrates, lectins serve many important roles in the innate immune defense by recognizing exogenous antigen [4]. In here, we found lectins also possess hemagglutinating activity in lamprey. Whether innate immune molecules involved in VLRs mediate adaptive immune response in lamprey is still unknown. In the future research, we are going to isolate and purify VLRs in lamprey serum, as well as to further elucidate the VLRs mediate innate immune molecules dependent immune defence in lamprey.

\section{Conflict of interest}

The authors declare no conflicts of interest or financial interests in any products or service mentioned in this article, including grants, employment, gifts, stock holding, or honoraria.

\section{Acknowledgements}

This work was supported by the grants from National Program on Key Basic Research Project (973 Program, 2013CB835304), National Natural Science Foundation of China (31170353, 31271323), Scientific Research Fund of Liaoning Provincial Education Department (L2011187) and Natural Science Foundation of Liaoning normal university (LS2015L010). 


\section{References}

1. Ogawa T, Watanabe M, Naganuma T, Muramoto K (2011) Diversified carbohydratebinding lectins from marine resources. J Amino Acids: 838914. [Crossref]

2. Rutishauser U, Sachs L (1975) Cell-to-cell binding induced by different lectins. J Cell Biol 65: 247-257. [Crossref]

3. Ourth DD, Rose WM, Siefkes MJ (2008) Isolation of mannose-binding C-type lectin from sea lamprey (Petromyzon marinus) plasma and binding to Aeromonas salmonicida. Vet Immunol Immunopathol 126: 407-412. [Crossref]
4. Guo XN, Jin XK, Li S, Yu AQ, Wu MH, et al. (2013) A novel C-type lectin from Eriocheir sinensis functions as a pattern recognition receptor with antibacterial activity. Fish Shellfish Immunol 35: 1554-1565. [Crossref]

5. Han Y, Liu X, Yu T, Shi B, Xiao R, et al. (2014) A novel member of B-cell linker protein identified in lamprey, Lampetra japonica. Acta Biochim Biophys Sin (Shanghai) 46: 526-530. [Crossref]

6. Han Y, Pang Y, Yu T, Xiao R, Shi B, et al. (2014) Lamprey serum can kill HeLa and NB4 tumor cells. Acta Biochim Biophys Sin (Shanghai) 46: 623-626. [Crossref]

7. Guo P, Hirano M, Herrin BR, Li J, Yu C, et al. (2009) Dual nature of the adaptive immune system in lampreys. Nature 459: 796-801. [Crossref]

Copyright: (2017 Han Y. This is an open-access article distributed under the terms of the Creative Commons Attribution License, which permits unrestricted use, distribution, and reproduction in any medium, provided the original author and source are credited. 